\title{
Methods to elicit probability distributions from experts: a systematic review of reported practice in health technology assessment
}

\author{
Authors: Bogdan Grigore, Jaime Peters, Christopher Hyde, Ken Stein \\ Peninsula Technology Assessment Group (PenTAG), Institute for Health Services Research, \\ University of Exeter Medical School, University of Exeter, UK
}

\section{Abstract}

BACKGROUND: Elicitation is a technique that can be used to obtain probability distribution from experts about unknown quantities. We conducted a methodology review of reports where probability distributions had been elicited from experts to be used in model-based health technology assessments.

METHODS: Databases including MEDLINE, EMBASE and the CRD database were searched from inception to April 2013. Reference lists were checked and citation mapping was also used. Studies describing their approach to the elicitation of probability distributions were included. Data was abstracted on pre-defined aspects of the elicitation technique. Reports were critically appraised on their consideration of the validity, reliability and feasibility of the elicitation exercise.

RESULTS: Fourteen articles were included. Across these studies, the most marked features were heterogeneity in elicitation approach and failure to report key aspects of the elicitation method. The most frequently used approaches to elicitation were the histogram technique and the bisection method. Only three papers explicitly considered the validity, reliability and feasibility of the elicitation exercises.

CONCLUSION: Judged by the studies identified in the review, reports of expert elicitation are insufficient in detail and this impacts on the perceived usability of expert-elicited probability distributions. In this context, the wider credibility of elicitation will only be improved by better reporting and greater standardisation of approach. Until then, the advantage of eliciting probability distributions from experts may be lost.

elicitation, expert opinion, subjective probabilities, health technology assessment, decision-analytic models, uncertainty

- The elicitation of probability distributions from experts to enhance the modelling process is an integral part of health technology assessment

- The majority of reports presenting expert elicitation of probability distribution were incomplete, making critical appraisal of these exercises difficult.

- By disseminating reports of such exercises conducted in health technology assessment, research is encouraged towards building a framework for conducting and evaluating the elicitation of probability distributions.

\section{Background}

Model-based economic evaluations carried out as part of Health Technology Assessments (HTA) rely on the synthesis of various types of scientific evidence and economic data to inform policy decisions on the optimal use of health care resources. When research data needed for cost-effectiveness decision analytic models are lacking, the opinion of clinical experts is a widely accepted source of evidence, routinely used despite expert opinion being regarded as the least reliable form of scientific evidence [1].

The process of formally capturing expert opinion for use in decision-analytic models in healthcare has been addressed in a number of papers [2,3], but very little of the literature is concerned with the elicitation of probability distributions from experts on unknown quantities. Recent developments in health research [4] acknowledge the 
usefulness of eliciting expert opinion in a probabilistic form, especially since probabilistic sensitivity analysis is increasingly becoming the norm in HTA [5], and also because value of information analyses can be conducted to direct further research [6]. However, good practice guidelines for decision-analytic modelling in HTA only recommend that the selection of experts and methods used are documented in a transparent manner [7] and do not provide guidance for eliciting probability distributions in particular. It may not be surprising that exercises eliciting probability distributions from experts are either not used or not reported in economic evaluations of health technologies.

Arguably, eliciting subjective probability distributions from experts is more complex than asking for point estimates, requires a degree of familiarity with statistics from the expert and usually a formal framework for the elicitation sessions. Many factors influence the elicitation process and researchers have to make methodological choices through all of the elicitation steps in order to achieve a reasonable balance between the accuracy of the elicitation, the resources allocated to the exercise and generally keeping within the time constraints of the HTA project (see Table 1 for examples).

Table 1. Aspects requiring a rational methodological choice by analysts doing elicitation

\begin{tabular}{|c|c|c|}
\hline Aspect & Examples & Description of potential trade-offs \\
\hline expert selection & $\begin{array}{l}\text { - which experts to select? } \\
\text { - the risk of motivational bias; }\end{array}$ & $\begin{array}{l}\text { - if experts are selected from a group of people with very similar } \\
\text { experiences, there is a risk of overrepresentation of a certain } \\
\text { opinion; however, on an obscure topic, the pool of available experts } \\
\text { may be very limited; } \\
\text { - sometimes, the experts with the best exposure to the relevant } \\
\text { topic may want to influence the outcome of the elicitation, } \\
\text { irrelevant of their true belief [37]; }\end{array}$ \\
\hline method selection & $\begin{array}{l}\text { - the elicitation method } \\
\text { - group or individual } \\
\text { approach } \\
\text { - face-to-face facilitated vs. } \\
\text { self-administered elicitation } \\
\\
\text { - calibration vs. equal } \\
\text { weighting for mathematical } \\
\text { synthesis }\end{array}$ & $\begin{array}{l}\text { - there is no agreement on which specific elicitation method is most } \\
\text { adequate for eliciting expert opinion in a probabilistic form [10]; } \\
\text { - the combination of opinions from individual experts can be done } \\
\text { through behavioural methods (e.g. consensus panels) or } \\
\text { mathematical methods (e.g. linear opinion pooling) [16]; } \\
\text { - a face-to-face facilitated session requires a trained analyst to } \\
\text { guide the experts through the questions, a process that is resource } \\
\text { intensive (considering also time and travel-related expenses), while } \\
\text { a self-administered questionnaire is easier to send out, but requires } \\
\text { careful preparation of the questionnaire, and response rates are } \\
\text { typically low [4]; } \\
\text { - through calibration, the opinion of more knowledgeable experts } \\
\text { can be better represented, but it is difficult to identify relevant } \\
\text { weighting criteria (which experts are better informed than } \\
\text { others)[23]; }\end{array}$ \\
\hline $\begin{array}{l}\text { questioning } \\
\text { strategy }\end{array}$ & - framing bias & $\begin{array}{l}\text { - the way questions are formulated may influence the estimates } \\
\text { [38]. }\end{array}$ \\
\hline
\end{tabular}

Selection of experts is a key step in a successful elicitation. Ideally, elicitation should be conducted with a number of experts that have the most expertise while not sharing the same perspective [8]. Availability and willingness to participate, as well as potential conflicts of interest also need to be taken into account [4]. There is little literature on the number of experts to elicit from, but research in other fields [9] suggest that between six and twelve experts should be included in most elicitation exercises. 
For the elicitation strategy, consideration needs to be given to whether the experts will be asked individually or as a group. Each has advantages and disadvantages and choices need to be made on a case-by-case basis [4].

Elicitation of probability distributions may prove difficult even for highly numeric health professionals, especially when eliciting unknown quantities [10]. To familiarise experts with the task and minimise the impact of heuristics, a preparation step is usually included in the elicitation exercise. Regardless of the elicitation method, usually only a small number of values are elicited from the expert, and an assumption is made about fitting a parametric distribution to these values. The question then is whether to elicit the values that represent the location and spread of these distributions directly or indirectly [11]. O'Hagan et al. provide a detailed overview of various elicitation methods [4], but only a few have been used by analysts in HTA [12].

One of the most common methods is the histogram technique [13]. This is a fixed interval method that allows quantities of interest to be elicited graphically. It is a discrete form of the probability density function (PDF) [4], where the expert is presented with a frequency chart on which he or she is asked to place a number of crosses (alternatively called chips or tokens). Placing all the crosses in one column would represent complete certainty, while placing all the crosses on the bottom row would represent complete uncertainty about the true value (Figure 1). The histogram technique has been used in several different forms, including the Trial Roulette [14], where the expert is presented with diagrams representing betting streets, similar to those used on a gaming table.

Another popular method to capture expert opinion based on the PDF is a hybrid method (also known as "six complementary intervals" [15]). First the lowest $(\mathrm{L})$, highest $(\mathrm{H})$ and most likely value $(\mathrm{M})$ of the probability of a Bernoulli trial are elicited. Intervals are automatically built using a formula to divide the distance between each extreme $(\mathrm{L}$ and $\mathrm{H})$ and $\mathrm{M}$ into three equal parts. Experts are then asked to enter the probability that their estimated value lays within each interval.

Another common method is the bisection method [10]. This is a variable interval method based on the cumulative distribution function, that entails a sequence of questions to elicit the median and the lower and upper quartiles; the main characteristic of this technique is that it requires only judgements of equal odds from the expert (e.g. the median would be a point such that the value of interest is equally likely to be less than or greater than it).

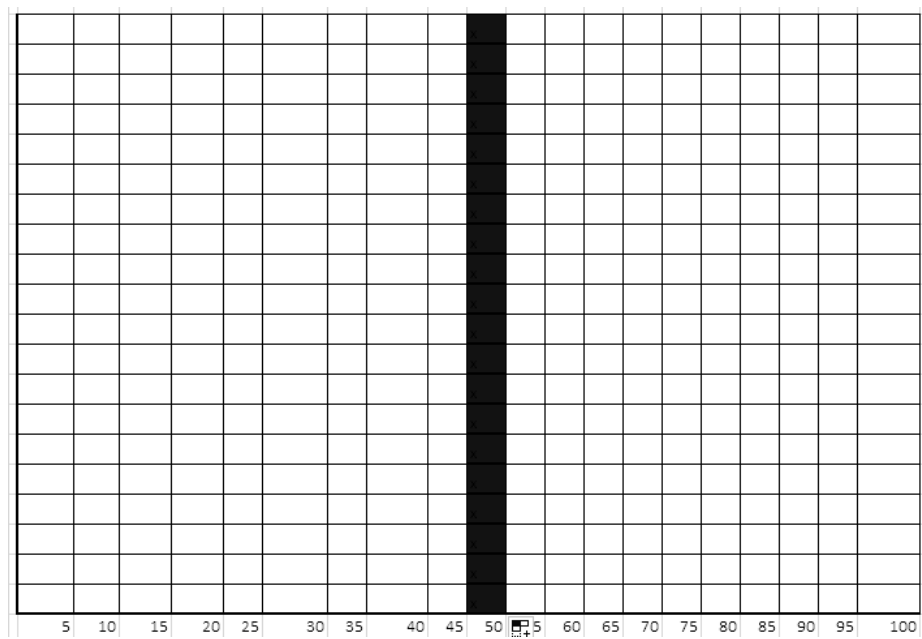

a) crosses indicate complete certainty that the value of interest is in the interval 45-50;

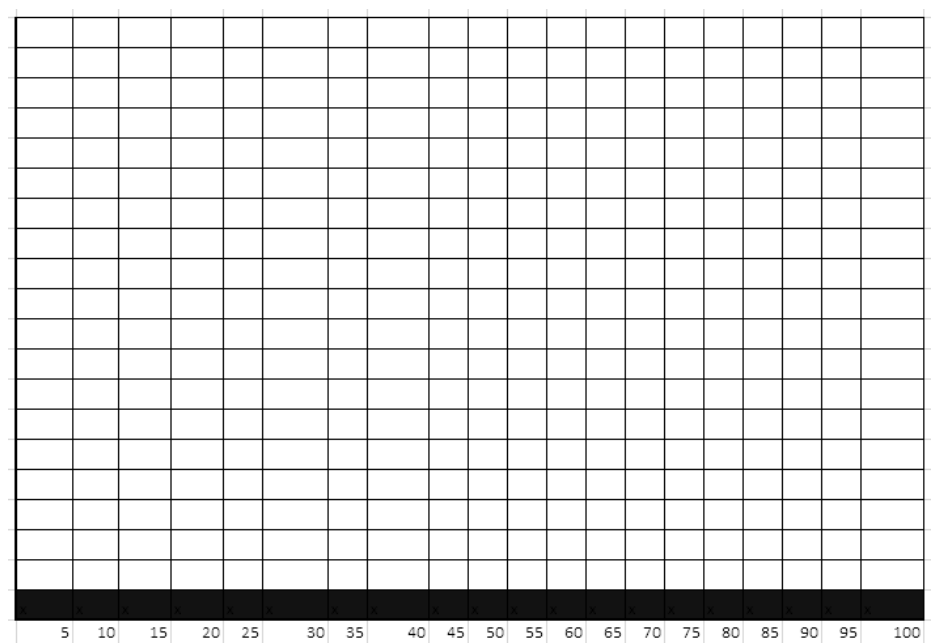

b) crosses indicate complete uncertainty, as the value of interest is equally likely to be anywhere between 0 and 100.

Figure 2. Complete certainty and complete uncertainty represented with the histogram technique.

When elicited probabilities are obtained from multiple experts, they can be aggregated, either through behavioural or mathematical methods. There is debate on which aggregation method is the most appropriate, with evidence favouring both $[4,16]$. In mathematical aggregation, another issue is the calibration of individual opinions (where opinions of experts assessed as "better" receive more weight in the combined distribution). In practice, experts 
could be equally weighted (so no expert is considered "better" than any other expert) [16], or certain criteria could be used to give different weights to the experts; for example, it is possible to validate an expert's opinion against existing data in seed questions (questions for which the answer is known) however, the ability to accurately recall available data is not an accurate predictor of judgement about unknown data [4].

There are currently no published guidelines on good practice elicitation of probability distributions in HTA, nor are there any agreed properties on which to measure elicitation methods. A number of studies [17-19] have, however, tried to define frameworks that would potentially allow the quantification of elicitation methods, by applying the criteria of measurement science [20] The properties considered for elicitation are validity, reliability, responsiveness and feasibility [18]. With the exception of validity, there has been little discussion of these properties within expert elicitation. In terms of validity, the assessor must be aware that what can be obtained from the expert is not the truth, but the expert's belief about the truth; consequently, a successful elicitation is one that faithfully records the expert's belief [4]. A good measure of face validity of elicited probabilities is obtained when experts are presented with a graphical representation of their expressed belief and are given the opportunity to adjust their response. Validation of the elicited probabilities can be performed by eliciting the same estimate from more than one expert [21], or by comparing them with available empirical data. Validation of expert's estimates against empirical data is usually not possible for the quantities of interest, but sometimes seed questions [22], are asked to the expert in order to have a measure of the reliability of expert's estimates.

Achieving a good balance among these factors is usually a challenge, with many practical limitations, and so the reporting of such considerations is important when evaluating the elicitation process.

The objective of this study was to systematically summarise any reported elicitation of probability distributions from experts undertaken to inform model-based economic evaluations in healthcare.

\section{Methods}

\section{- Search strategy}

Identifying studies that reported the formal use of expert opinion to inform decision models was challenging, as pilot searches indicated that not all modelling exercises report in their abstracts whether expert opinion was captured and used as part of the research, much less if probability distributions were elicited.

The search strategy was constructed from a selection of keywords collected from relevant papers uncovered by the pilot search. Keywords were grouped into three categories defining the type of studies (economic evaluations, HTAs), type of input (expert opinion/knowledge/judgement, expert panel, advisory group) and outcome (subjective probabilities, Bayesian priors) (see web appendix for detailed search strategy). Mapping of keywords to subject headings was not possible, as no topics or MeSH (Medical Subject Heading) terms were identified for expert elicitation, and use of generic headings like "expert testimony" did not result in any relevant results.

The following databases were searched: EMBASE (1974 to April 2013), MEDLINE (In-Process \& Other Non-Indexed Citations and Ovid MEDLINE(R) 1946 to April 2013), Web of Science, CINAHL, the CRD database (including the NHSEED, HTA and DARE databases).

\section{- Inclusion and exclusion criteria}

After removal of duplicate articles across databases, the titles and abstracts were screened by two reviewers (BG and JP). Articles describing a decision analytic model as part of an HTA, which used expert opinion, were included for full text screening. Any disagreements between the two reviewers were resolved by discussion.

The remaining articles were screened in full text and those that contained only elicited point estimates (not probability distributions) or did not describe the elicitation methods were excluded. 
The references of included articles and papers quoting these articles were searched for other potentially eligible studies, through the Quotation Map tool from Web of Science. Where several papers described aspects of the same modelling process, only the reference containing the most complete account of the elicitation was included.

\section{- Data extraction}

Using a data extraction tool constructed specifically for this task, based on the elicitation methods literature [4, 9, 23], the details shown in Table 2 were extracted.

\section{- Critical appraisal}

We have sought to determine whether included articles considered any of the following properties in the reporting of the elicitation exercise:

- validity: face validity, whether the experts were asked if the elicited probability distributions reflected their beliefs, or criterion validity, where the elicited distributions are validated against available data [20];

- reliability: reproducibility of the reported exercise. Whether there is sufficient description of the method and bias management strategies; in particular, the preparation and possible calibration of the experts

- feasibility: reporting and discussion of the complexity of the task and the logistics related to the elicitation exercise, any choices and trade-offs made in building the elicitation exercise, and how these may have been reflected in response rates and proportion of valid responses; dealing with invalid responses or failed exercises is also important from a feasibility point of view.

\section{Table 2. Aspects recorded during data extraction}

\begin{tabular}{|l|l|}
\hline 1. Preparation of the elicitation & - purpose of elicitation; type and format of parameters (e.g. epidemiological, \\
& clinical, resource use etc.); \\
& - reporting of elicitation planning, piloting; \\
& -elicitation strategy: \\
& - level of elicitation (individual/group elicitation); \\
& - elicitation method, format of estimates: (e.g. intervals, distributions, shape etc.); \\
& - mode of administration (e.g. interview, paper, PC etc.); facilitated or not; \\
& - selection of experts \\
\hline 2. Elicitation session & - reporting of experts preparation \\
& - opportunity of revision by experts, feedback \\
\hline 3. Post-elicitation & - fit/assignment of smooth function \\
& - aggregation of estimates from individual experts \\
\hline 4. Reported critical assessment & -consideration of validity \\
& -consideration of feasibility \\
& -consideration of debiasing strategies \\
\hline
\end{tabular}

\section{Results}

Fourteen articles describing elicitation exercises for use in a HTA context were included. (Figure 2) Of these 14, ten were identified from the database search and four from screening references and citations of included studies. See Table 3 for details on the included papers.

\section{- Summary statistics}

Of the 14 included studies, two were from the grey literature $[24,25]$, as they were publicly available and met the inclusion criteria. Four of the 12 were exclusively dedicated to the description of the elicitation exercise, independent of the modelling process $[12,21,26,27]$, and one [28] was a methodological paper which also reported an elicitation 
study. The rest of the studies reported the elicitation exercise with less detail, but explicitly indicated elicitation of probability distributions for a number of model parameters.

\section{- Preparation of the elicitation}

All studies report using health professionals as experts, but three studies do not report the number of experts involved. The median number of experts included in the other ten studies is 5 (mean 9.2, ranging from 3 to 23 experts per study). Details of the strategy used to select experts were reported in seven studies; in six of these [12, 14, 21, 26, $27,29]$ substantive expertise is an explicit criterion for expert selection. Two studies $[12,26]$ report specifically selecting experts with different experiences, while in Stevenson et al. [30], the experts were part of the study team. One study [28] specifically targets geographically dispersed experts, in an effort to explore the wide-spread collection of quality data. No further aspects of expert selection are reported in the studies.

The elicitation method used is arguably the most important characteristic of the exercise, and all reports contain some information on this. Four studies $[12,25,26,29]$ report constructing pilot exercises to assess various methods to conduct and combine elicitations. Ease of use was an important factor in choosing the appropriate method, as it predicted higher compliance by the experts, especially when a facilitator was not available $[25,26,28]$.

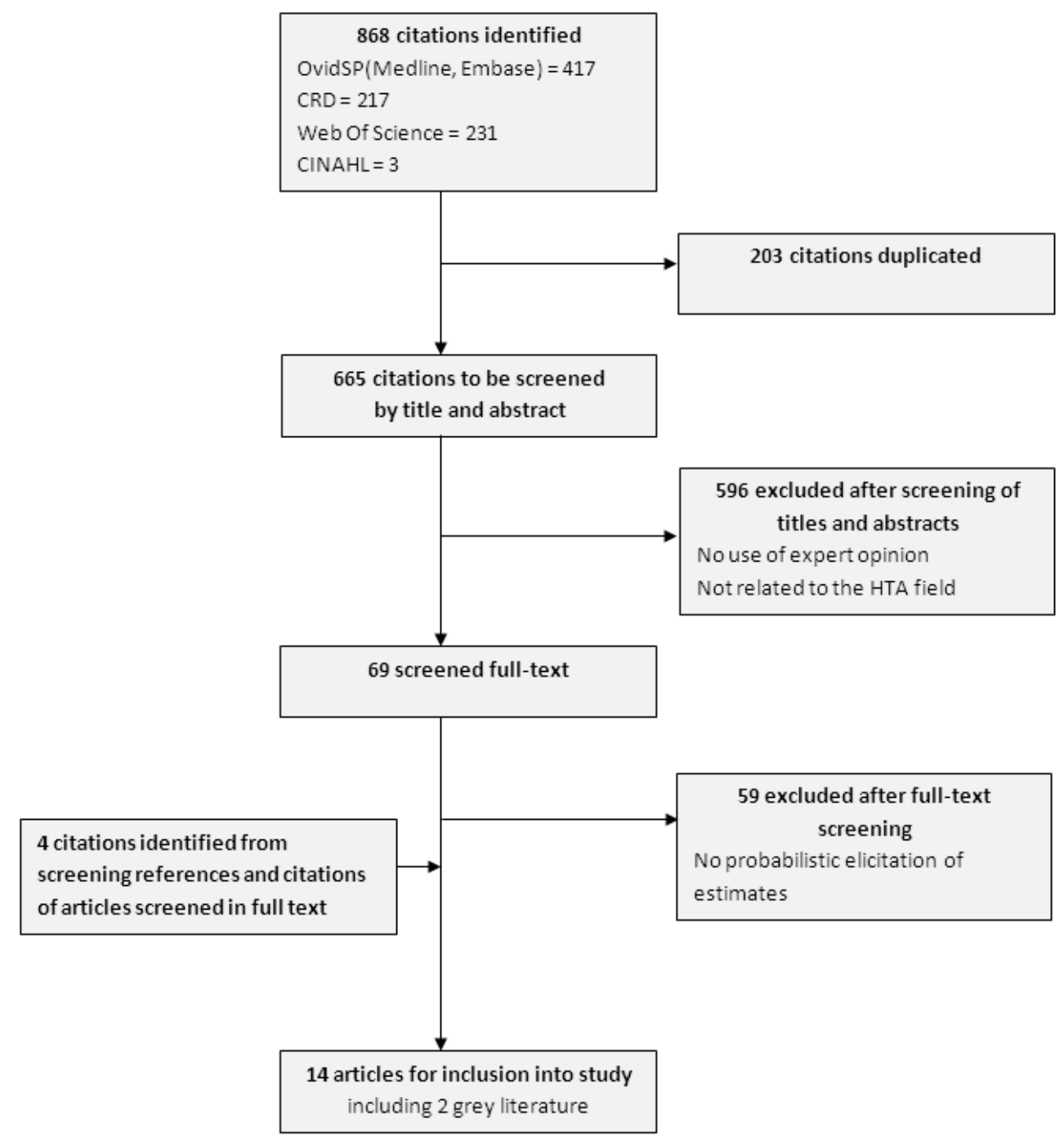

Figure 2. The Flow diagram of search results

Eleven of the fourteen studies report providing training in probability elicitation for the participating experts prior to undertaking the elicitation session. In seven studies [14, 21, 26-29], experts were given written instructions for completing the questionnaires and in five of these background information on the modelling exercise was given. Four studies reported the presence of a facilitator during the elicitation [12, 21, 31, 32], and in one study [12], experts 
attended a 2 hour preparatory training session. Details on the training of experts could not be obtained from the remaining studies. Thirteen studies report conducting the elicitation with experts individually, with only one study [31], using a group consensus method to elicit the probability distributions. See Table 3 for further details.

All included studies used elicitation to inform effectiveness (for treatments), performance (for diagnostic tests) or disease progression parameters, with only one study eliciting resource use [21]. The elicited parameters were in the form of a proportion in six studies, a rate in three studies, time to event in three and, relative risk in two studies.

In three studies experts were asked directly for their estimates of:

- the mean and the lower and upper $95 \%$ confidence limits [33];

- the mode (described as "the most likely value") and the lower and upper $95 \%$ confidence limits [25];

- various unspecified quantiles [31].

Four studies [12, 14, 27, 29] used the histogram technique and three studies $[21,28,30]$ used the bisection method. Leal et al. [26] report the use of a method based on the "six complementary intervals" method (the hybrid method), but using instead only four intervals. Meads et al. [32] use the allocation of points technique (similar to the histogram technique in that the experts allocate a total of 100 points to a number of fixed, predefined value ranges). One study [34] does not explicitly report the elicitation method used, however does provide values for the median, $10^{\text {th }}$ and $90^{\text {th }}$ percentiles, while another study [24] gives no indication of the elicitation method used.

Five clinicians participated in a consensus reaching exercise in Girling et al. [31]. The elicitation entailed the discussion of a small number of quantiles for each parameter. It is not clear from the paper which quantiles were elicited, and although the description fits with the bisection method of elicitation, the actual method used was not reported. Garthwaite et al. [21] also elicited quantities with several covariates using specially developed software.

Beside the facilitated sessions, which favoured interaction with the facilitator [12, 32], other studies report how experts were given the opportunity to adjust their elicitations: either a summary of their answers at the end of the session [12, 26-28] or by seeing the smoothed aggregated distribution of all the experts [34].

In eleven studies, a smooth function was fitted to the individual elicited distributions, and for five studies [12, 14, $26,29,32$ ] the smooth function was fitted to the aggregated estimates. In the group elicitation study [31], a computergenerated density function was presented in real time to the clinicians, this was amended as necessary until the whole group was satisfied with the shape.

Analysts fitted beta $[12,14,25,28,29,33,34]$, normal [12, 30, 32, 34] or Weibull [24] distributions to the elicited estimates. Best fit was determined mathematically by the method of moments [12] or the least squares approach [28, 30]. Leal et al. [26] evaluated goodness of fit by drawing the aggregate histogram and PDF curve together. To check the adequacy of the fitted distribution, Stevenson et al. [30] discussed additional quantiles like the $10^{\text {th }}$ and the $90^{\text {th }}$ percentiles. In the case of disagreement, the expert would either modify his or her initial judgements or an alternative parametric distribution would be considered as appropriate. One study reports fitting a normal distribution to multivariate parameters [21]. Although it appears that all elicitation exercises included a fitting of a smooth function, no details are provided in the remaining studies. The issue of uncertainty introduced by smooth function fitting was commented by only one study [12].

Seven papers include sample questions from the elicitation questionnaire $[8,12,14,21,26,28,29]$, in order to give a clearer image of the elicitation. Sperber et al. [28] also provide the complete elicitation tool used as supplementary, web-only material.

\section{- Post-elicitation}

Mathematical aggregation of the elicited distributions across experts was reported in nine studies. Aggregation of data was conducted by either linearly pooling individual opinions [12, 25-27, 29], using a random effects model [27, 33] or by sampling distributions of each expert and then combining the individual samples [30]. Some studies report using different weights for individual distributions. Calibration of individual experts was done through seeding questions (questions whose answers are known to the investigator, but not to the expert) [27] or a synthetic score based on individual characteristics of the expert (i.e. years of experience) [25]. Bojke et al. [27] compared the results of 
aggregation using linear pooling and a random effects model, with and without calibration. They found that results were sensitive to aggregation method used and whether calibration was used or not [27]. Soares et al. [12] evaluated the use of calibration in their pilot exercise and reported differences between the combined estimates with and without calibration. However, they discarded calibration for the case study because of difficulties in choosing the most appropriate criteria for weighting the individual elicitations. Sperber et al. [28] also explored several aggregation methods and concluded that unweighted opinion pooling was the optimal method.

In Garthwaite et al. [21], responses for the same question from different experts were empirically compared as a measure of validity and only the estimates of a single expert were used for each parameter. As part of their feasibility assessment, non-facilitated elicitation exercises translated in a mean response rate of $40.63 \%$, while in elicitation conducted through facilitated sessions, the issue of response rate is not discussed.

Several studies report experts failing to complete the exercise. The main reason for this was the inability to use the software delivering the questions $[26,27]$. Other reasons why responses could not be used were invalid answers [12], outlying estimates [25] or the questions being altered by the expert so they could give answers based on data available to them [21]. One paper [28] reports inconsistencies between the expert's stated uncertainty and the provided values, by stating that it wasn't their area of expertise, yet stating $100 \%$ certainty of the value lying between 0 and 0.1 .

\section{Critical appraisal}

In twelve of the included articles, the reports suggest that aspects of validity, reliability and feasibility of the elicitation exercise were considered (see Table 4). However, with very few exceptions [12, 21, 28], based on the study reports, these properties were not explored explicitly.

Nine studies (64\%) mentioned steps to assess the validity of the elicited distributions, usually by asking the expert to reflect on the elicited distributions; ten studies (71\%) consider aspects of reliability of the elicitation exercise (such as providing sufficient description of the method, containing details on elicitation training or pooling distributions elicited from several experts) and eight studies (57\%) report aspects related to the feasibility of the elicitation exercise.

Overall, reporting on the aspects of validity, reliability and feasibility of the elicitation exercises was insufficient across these fourteen papers.

\section{Discussion}

This review uncovered a relatively small number of studies reporting the use of elicitation of probability distributions in HTA, yet these studies were heterogeneous in their reporting of the conduct of the elicitation exercises.

The dominant observed approach to elicitation was getting individual estimates from several experts and combining them mathematically, without calibration. The most frequently used elicitation methods were the histogram technique and the bisection method, with a number of variations. The preferred aggregation methods were linear pooling and random effects meta-analysis. Calibration was considered in some studies but not used, as choosing the appropriate criteria to calibrate was reported to be a significant deterrent. Other methods of elicitation have been used, including consensus reaching group elicitation.

Use of strategies for controlling bias was reported across the studies, but varied greatly. Some studies report using empirical measurements for selecting the elicitation method, like piloting of different methods and asking experts for their preferences for one method or the other. Most of the elicited parameters were related to the effectiveness of intervention.

There were a number of reporting limitations in the included studies. Some studies omit reporting relevant data such as the expert selection strategy, the elicitation or aggregation methods. These omissions may be due to limited word counts or because these aspects were not considered relevant. This may negatively affect the perceived quality of the elicitation, even if all reasonable steps were taken to ensure an adequate procedure. Furthermore, there are inconsistencies in terminology, as five different studies report using a very similar method (the histogram technique), but name it in three different ways. This lack of standardised language makes it difficult to categorise and index the articles on the elicitation method used. 
The use of expert elicitation of probability distributions is a way to enhance the quality of expert opinion in HTA and is useful in exploring the overall uncertainty that the decision makers are confronted with, as well as in directing further research. However, the perceived complexity of expert elicitation may limit its use. Trade-offs are inherent to the elicitation process, as assessors need to balance limited resources and deadlines with achieving optimal response from the experts [35]. In the included studies, most choices were made with investigators reportedly being aware of potential trade-offs. For instance, there was a significant difference between the rate (and quality) of responses between facilitated and non-facilitated elicitation exercises, with the latter having a low response rate. This was attributed in several occasions to the technical burden on the experts to provide probability distributions in the absence of sufficient statistical knowledge. Some studies indicated that having a facilitator present was not possible because of time constraints and, in at least two studies, investigators anticipated this trade-off and recruited more experts.

Our review is limited by elicitation of probability distributions not being indexed as a subject heading term in the usual search engines and such terms not being present in the abstract or keywords of relevant articles. We tried to deal with this shortcoming by adopting a search strategy that included specific terms such as opinion/knowledge/judgement and subjective probabilities. Although it is possible that this search missed relevant studies if these terms were not used, screening the references of the included papers identified further relevant studies. However, it is still possible that relevant papers were not identified in our search strategy.

No dedicated framework for the critical appraisal of elicitation exercises exists. However, we determined whether authors had considered aspects of validity, reliability and feasibility of the elicitation. The reports suggest that these aspects were considered to a certain extent in the majority of the studies, but not explicitly so. More research is needed to define measurement criteria for the elicitation methods used in HTA. Until these become available, elicitation exercises should be approached alongside strategies that consider the validity and reliability, and should be reported with consideration of methodological trade-offs and the expected impact on the elicitation outcomes. We consider that more complete reporting of the elicitation exercises in the future would help determine whether these aspects had been considered.

Although a checklist for reporting items could be useful to this end, further work is needed in the development of such guidelines [36]. However, it is our opinion that, as a minimum, elements defining the validity and reliability of the elicitation exercise (method description, selection and preparation of experts, calibration and synthesis of individual distributions) should always be reported explicitly in relation to an elicitation exercise. Aspects outside of the analysts' control (like availability of experts) are also important and should be reported transparently as part of the feasibility assessment. Where the description of elicitation is limited by word count, these reports could be provided as web-only appendices.

\section{Conclusions}

This review summarises the reported current use of expert elicitation of probability distributions in HTAs. Elicitation is a complex process and, as our review shows, it can be difficult to conduct and report. This affects the perceived quality of the exercise and understates the added value of expert opinion obtained as probability distributions.

Based on the findings of this study, we recommend that reporting of elicitation exercises informing HTAs should be more complete, with any consideration of validity, reliability or feasibility explicitly presented. Further efforts should be made towards agreement of definition and content of these measurement properties, in order to improve standardisation of approach. This will facilitate the critical appraisal of reported expert elicitations, greatly enhancing their credibility as genuine tools for HTA, as will the development of reporting guidelines for the elicitation or probability distributions.

\section{Acknowledgements}


This research was funded by the National Institute of Health Research (NIHR) Collaboration for Leadership in Applied Health Research and Care (CLAHRC) for the South West Peninsula. The views expressed in this publication are those of the authors and not necessarily those of the NHS, the NIHR or the Department of Health.

Author contributions All authors contributed to the conception of the study. BG and JP collected and extracted the data. All authors contributed to interpretation of the data and to the final manuscript. Ken Stein is the guarantor for the overall content of this paper.

Conflicts of interest BG has no conflicts of interest. JP has no conflicts of interest. CH has no conflicts of interest. KS has no conflicts of interest.

\section{References}

1. Evans D. Hierarchy of evidence: a framework for ranking evidence evaluating healthcare interventions. J Clin Nurs. 2003 Jan;12(1):77-84.

2. Evans C, Crawford B. Expert judgement in pharmacoeconomic studies: guidance and future use. Pharmacoeconomics. 2000;17(6):545-53.

3. Sullivan W, Payne K. The Appropriate Elicitation of Expert Opinion in Economic Models: Making Expert Data Fit for Purpose. Pharmacoeconomics. 2011;29(6):455-9.

4. O'Hagan A, Buck CE, Daneshkhah A, Eiser JR, Garthwaite PH, Jenkinson DJ, et al. Uncertain Judgements: Eliciting Experts' Probabilities. Chichester: Wiley; 2006.

5. Claxton K, Sculpher M, McCabe C, Briggs A, Akehurst R, Buxton M, et al. Probabilistic sensitivity analysis for NICE technology assessment: not an optional extra. Health economics. 2005;14(4):339-47.

6. Claxton KP, Sculpher MJ. Using Value of Information Analysis to Prioritise Health Research. Pharmacoeconomics. 2006;24(11):1055-68.

7. Philips Z, Ginnelly L, Sculpher M, Claxton K, Golder S, Riemsma R, et al. Review of guidelines for good practice in decision-analytic modelling in health technology assessment. Health Technology Assessment. 2004;8(3).

8. Winkler RL, Poses RM. Evaluating and combining physicians' probabilities of survival in an intensive care unit. Management science. 1993:1526-43.

9. Knol AB, Slottje P, van der Sluijs JP, Lebret E. The use of expert elicitation in environmental health impact assessment: a seven step procedure. Environmental health : a global access science source. 2010;9:19.

10. Garthwaite PH, Kadane JB, O'Hagan A. Statistical methods for eliciting probability distributions. Journal of the American Statistical Association. 2005;100(470):680-701.

11. Winkler RL. The assessment of prior distributions in Bayesian analysis. Journal of the American Statistical Association. 1967;62(319):776-800.

12. Soares MO, Bojke L, Dumville J, Iglesias C, Cullum N, Claxton K. Methods to elicit experts' beliefs over uncertain quantities: application to a cost effectiveness transition model of negative pressure wound therapy for severe pressure ulceration. Statistics in Medicine. 2011;30(19):2363-80.

13. Van Noortwijk JM, Dekker A, Cooke RM, Mazzuchi TA. Expert judgment in maintenance optimization. Reliability, IEEE Transactions on. 1992;41(3):427-32.

14. Speight PM, Palmer S, Moles DR, Downer MC, Smith DH, Henriksson M, et al. The cost-effectiveness of screening for oral cancer in primary care. Health technology assessment (Winchester, England). 2006;10(14):1-144, iii-iv.

15. Phillips L, Wisbey $\mathrm{S}$. The elicitation of judgemental probability distributions from groups of experts: a description of the methodology and records of seven formal elicitation sessions held in 1991 and 1992. Report nss/r282 Nirex UK, Didcot, UK. 1993.

16. Clemen RT, Winkler RL. Aggregating probability distributions. Advances in decision analysis: From foundations to applications. 2007:154-76. 
17. Kadane J, Wolfson L. Experiences in elicitation. Journal of the Royal Statistical Society: Series D (The Statistician). 1998;47(1):3-19.

18. Johnson SR, Tomlinson GA, Hawker GA, Granton JT, Feldman BM. Methods to elicit beliefs for Bayesian priors: a systematic review. Journal of Clinical Epidemiology. 2010;63(4):355-69.

19. Kinnersley N, Day S. Structured approach to the elicitation of expert beliefs for a Bayesian-designed clinical trial: a case study. Pharmaceutical statistics. 2013.

20. Keszei AP, Novak M, Streiner DL. Introduction to health measurement scales. Journal of psychosomatic research. 2010;68(4):319-23.

21. Garthwaite PH, Chilcott JB, Jenkinson DJ, Tappenden P. Use of expert knowledge in evaluating costs and benefits of alternative service provisions: a case study. International Journal of Technology Assessment in Health Care. 2008;24(3):350-7.

22. Cooke RM. Experts in uncertainty: opinion and subjective probability in science: Oxford University Press, USA; 1991.

23. Wolpert RL. Eliciting and combining subjective judgments about uncertainty. International Journal of Technology Assessment in Health Care. 1989;5(4):537-57.

24. Brodtkorb TH. Cost-effectiveness analysis of health technologies when evidence is scarce: Linkoping University; 2010.

25. Haakma W. Expert Elicitation to Populate Early Health Economic Models of Medical Diagnostic Devices in Development. Twente: University of Twente; 2011.

26. Leal J, Wordsworth S, Legood R, Blair E. Eliciting expert opinion for economic models: An applied example. Value in Health. 2007 May;10(3):195-203.

27. Bojke L, Claxton K, Bravo-Vergel Y, Sculpher M, Palmer S, Abrams K. Eliciting distributions to populate decision analytic models. Value in Health. 2010 July-August;13(5):557-64.

28. Sperber D, Mortimer D, Lorgelly P, Berlowitz D. An Expert on Every Street Corner? Methods for Eliciting Distributions in Geographically Dispersed Opinion Pools. Value in Health. 2013.

29. McKenna C, McDaid C, Suekarran S, Hawkins N, Claxton K, Light K, et al. Enhanced external counterpulsation for the treatment of stable angina and heart failure: a systematic review and economic evaluation (Structured abstract). Health Technology Assessment2009. p. 1-90.

30. Stevenson MD, Oakley JE, Lloyd Jones M, Brennan A, Compston JE, McCloskey EV, et al. The cost-effectiveness of an RCT to establish whether 5 or 10 years of bisphosphonate treatment is the better duration for women with a prior fracture. Medical Decision Making. 2009 November-December;29(6):678-89.

31. Girling AJ, Freeman G, Gordon JP, Poole-Wilson P, Scott DA, Lilford RJ. Modeling payback from research into the efficacy of left-ventricular assist devices as destination therapy (Structured abstract). International Journal of Technology Assessment in Health Care2007. p. 269-77.

32. Meads C, Auguste P, Davenport C, Małysiak S, Sundar S, Kowalska M, et al. Positron emission tomography/computerised tomography imaging in detecting and managing recurrent cervical cancer: systematic review of evidence, elicitation of subjective probabilities and economic modelling. Health technology assessment (Winchester, England). 2013;17(12):1-323.

33. Colbourn T, Asseburg C, Bojke L, Philips Z, Claxton K, Ades A, et al. Prenatal screening and treatment strategies to prevent group $B$ streptococcal and other bacterial infections in early infancy: Cost-effectiveness and expected value of information analyses. Health Technology Assessment. 2007 Aug;11(29):IX-+.

34. Stevenson MD, Oakley JE, Chick SE, Chalkidou K. The cost-effectiveness of surgical instrument management policies to reduce the risk of VCJD transmission to humans. J Oper Res Soc. 2008;60(4):506-18.

35. O'Leary RA, Choy SL, Murray JV, Kynn M, Denham R, Martin TG, et al. Comparison of three expert elicitation methods for logistic regression on predicting the presence of the threatened brush-tailed rock-wallaby Petrogale penicillata. Environmetrics. 2009;20(4):379-98.

36. Moher D, Schulz KF, Simera I, Altman DG. Guidance for Developers of Health Research Reporting Guidelines. PLoS Med. 2010;7(2):e1000217.

37. Mazur A. II Disputes between experts. Minerva. 1973;11(2):243-62.

38. Tversky A, Kahneman D. The framing of decisions and the psychology of choice. science. 1981;211(4481):453-8. 
Table 3. Characteristics of the included studies

\begin{tabular}{|c|c|c|c|c|c|c|c|c|}
\hline Article & Purpose of elicitation & $\begin{array}{l}\text { Types of parameters } \\
\text { elicited }\end{array}$ & $\begin{array}{l}\text { Format of } \\
\text { parameters }\end{array}$ & $\begin{array}{l}\text { Format of } \\
\text { estimates }\end{array}$ & $\begin{array}{l}\text { Administration } \\
\text { method }\end{array}$ & $\begin{array}{l}\text { Feedback / } \\
\text { Possibility of } \\
\text { iteration by } \\
\text { expert }\end{array}$ & $\begin{array}{l}\text { Smooth } \\
\text { function fit } \\
\text { (level, } \\
\text { distribution } \\
\text { used) }\end{array}$ & Aggregation \\
\hline $\begin{array}{l}\text { Bojke, } 2010 \\
\text { [27] }\end{array}$ & $\begin{array}{l}\text { Probabilistic decision analytic } \\
\text { model to assess the cost- } \\
\text { effectiveness of infliximab and } \\
\text { etanercept for the treatment of } \\
\text { active psoriatic arthritis (PSA), } \\
\text { compared with palliative care }\end{array}$ & $\begin{array}{l}\text { Effectiveness parameters } \\
\text { Clinical parameters }\end{array}$ & Rates & $\begin{array}{l}\text { Histogram } \\
\text { technique }\end{array}$ & $\begin{array}{l}\text { Computer-based; } \\
\text { non-facilitated }\end{array}$ & $\mathrm{Y}$ & NR & $\begin{array}{l}\text { linear pooling } \\
\text { and random } \\
\text { effects meta- } \\
\text { analysis (both } \\
\text { with and } \\
\text { without } \\
\text { weighting) }\end{array}$ \\
\hline $\begin{array}{l}\text { Brodtkorb } \\
2010[24]\end{array}$ & $\begin{array}{l}\text { economic evaluation for prosthetic } \\
\text { knees for amputees }\end{array}$ & Effectiveness parameters & $\begin{array}{l}\text { Rates } \\
\text { Time to event }\end{array}$ & NR & NR & & Y (Weibull) & NR \\
\hline $\begin{array}{l}\text { Colbourn, } \\
2007[33]\end{array}$ & $\begin{array}{l}\text { Cost-effectiveness of prenatal } \\
\text { screening and treatment strategies } \\
\text { to prevent group B streptococcal } \\
\text { and other bacterial infections in } \\
\text { early infancy }\end{array}$ & Effectiveness parameters & Relative risk & Mean and $95 \% \mathrm{Cl}$ & $\begin{array}{l}\text { Questionnaire; } \\
\text { facilitation NR }\end{array}$ & $\mathrm{NR}$ & $\begin{array}{l}\text { Beta } \\
\text { distribution }\end{array}$ & $\begin{array}{l}\text { random } \\
\text { effects meta- } \\
\text { analysis using } \\
\text { WinBUGS }\end{array}$ \\
\hline $\begin{array}{l}\text { Garthwaite, } \\
2008[21]\end{array}$ & $\begin{array}{l}\text { Model for care pathways in } \\
\text { colorectal cancer }\end{array}$ & $\begin{array}{l}\text { Epidemiological } \\
\text { parameters } \\
\text { Clinical parameters } \\
\text { Resource use }\end{array}$ & $\begin{array}{l}\text { Time to event } \\
\text { Proportions }\end{array}$ & $\begin{array}{l}\text { Median and } \\
\text { quartiles } \\
\text { (bisection } \\
\text { method) or } \\
\text { median and } \\
\text { min/max }\end{array}$ & $\begin{array}{l}\text { Computer-based; } \\
\text { facilitated }\end{array}$ & $\mathrm{Y}$ & $\begin{array}{l}Y \\
\text { (only } \\
\text { multivariate; } \\
\text { as normal } \\
\text { distributions) }\end{array}$ & $\mathrm{N}$ \\
\hline $\begin{array}{l}\text { Girling, } \\
2007[31]\end{array}$ & $\begin{array}{l}\text { early cost-effectiveness assessment } \\
\text { of left-ventricular assist devices } \\
\text { (LVAD) }\end{array}$ & Effectiveness parameters & $\begin{array}{l}\text { Proportion } \\
\text { Time to event }\end{array}$ & quantiles & $\begin{array}{l}\text { Group elicitation; } \\
\text { Computer-based; } \\
\text { facilitated }\end{array}$ & $\mathrm{Y}$ & $\begin{array}{l}Y \\
\text { (in real time) }\end{array}$ & behavioural \\
\hline $\begin{array}{l}\text { Haakma } \\
2011[25]\end{array}$ & $\begin{array}{l}\text { Early evaluation of value of } \\
\text { photoacoustic mammography }\end{array}$ & Performance parameters & Rates & $\begin{array}{l}\text { Mode, lower and } \\
\text { upper limits (95\% } \\
\text { Cl) }\end{array}$ & $\begin{array}{l}\text { Face-to-face } \\
\text { interview }\end{array}$ & & $\begin{array}{l}Y \\
\text { normal }\end{array}$ & $\begin{array}{l}\text { Y (linear } \\
\text { pooling } \mid \text { ) }\end{array}$ \\
\hline $\begin{array}{l}\text { Leal, } 2007 \\
{[26]}\end{array}$ & $\begin{array}{l}\text { Economic evaluation of the long- } \\
\text { term costs and effects of } \\
\text { alternative approaches to } \\
\text { diagnosing and managing } \\
\text { hypertrophic cardiomyopathy } \\
\text { (HCM) for those at risk of sudden }\end{array}$ & $\begin{array}{l}\text { Epidemiological } \\
\text { parameters } \\
\text { Performance parameters }\end{array}$ & Proportions & $\begin{array}{l}\text { Mode and upper } \\
\text { and lower limit }\end{array}$ & $\begin{array}{l}\text { Email; } \\
\text { Computer-based; } \\
\text { non-facilitated }\end{array}$ & $\mathrm{Y}$ & $\begin{array}{l}Y \\
\text { (to } \\
\text { aggregated) }\end{array}$ & $\begin{array}{l}\text { Linear } \\
\text { pooling }\end{array}$ \\
\hline
\end{tabular}




\begin{tabular}{|c|c|c|c|c|c|c|c|c|}
\hline Article & Purpose of elicitation & $\begin{array}{l}\text { Types of parameters } \\
\text { elicited }\end{array}$ & $\begin{array}{l}\text { Format of } \\
\text { parameters }\end{array}$ & $\begin{array}{l}\text { Format of } \\
\text { estimates }\end{array}$ & $\begin{array}{l}\text { Administration } \\
\text { method }\end{array}$ & $\begin{array}{l}\text { Feedback / } \\
\text { Possibility of } \\
\text { iteration by } \\
\text { expert }\end{array}$ & $\begin{array}{l}\text { Smooth } \\
\text { function fit } \\
\text { (level, } \\
\text { distribution } \\
\text { used) }\end{array}$ & Aggregation \\
\hline & cardiac death $(S C D)$ & & & & & & & \\
\hline $\begin{array}{l}\text { Meads, } \\
2013[32]\end{array}$ & $\begin{array}{l}\text { Economic modelling of PET-CT/CT } \\
\text { in detecting and managing } \\
\text { recurrent cervical cancer }\end{array}$ & $\begin{array}{l}\text { Epidemiological } \\
\text { parameters } \\
\text { Performance parameters }\end{array}$ & Proportions & $\begin{array}{l}\text { Allocation of } \\
\text { points technique }\end{array}$ & $\begin{array}{l}\text { Pen-and-paper; } \\
\text { facilitated }\end{array}$ & NR & $\begin{array}{l}\mathrm{Y} \\
\text { to } \\
\text { aggregated, } \\
\text { normal }\end{array}$ & $\begin{array}{l}\mathrm{Y} \\
\text { (details are } \\
\text { unclear) }\end{array}$ \\
\hline $\begin{array}{l}\text { McKenna, } \\
2009[29]\end{array}$ & $\begin{array}{l}\text { Model for the cost-effectiveness of } \\
\text { enhanced external } \\
\text { counterpulsation }\end{array}$ & Effectiveness parameters & Proportions & $\begin{array}{l}\text { Frequency chart } \\
\text { (histogram) }\end{array}$ & $\begin{array}{l}\text { Computer-based; } \\
\text { facilitation NR }\end{array}$ & $\mathrm{Y}$ & $\begin{array}{l}\text { Y } \\
\text { to } \\
\text { aggregated, } \\
\text { beta }\end{array}$ & $\begin{array}{l}\text { Linear } \\
\text { pooling }\end{array}$ \\
\hline $\begin{array}{l}\text { Soares, } \\
2011[12]\end{array}$ & $\begin{array}{l}\text { Markov decision model for } \\
\text { negative pressure wound therapy } \\
\text { for severe pressure ulceration }\end{array}$ & $\begin{array}{l}\text { Effectiveness parameters } \\
\text { Clinical parameters }\end{array}$ & Proportions & $\begin{array}{l}\text { Histogram } \\
\text { technique }\end{array}$ & $\begin{array}{l}\text { Computer-based; } \\
\text { facilitated }\end{array}$ & $\mathrm{Y}$ & $\begin{array}{l}Y \\
\text { (to } \\
\text { aggregated; } \\
\text { beta or } \\
\text { normal) }\end{array}$ & $\begin{array}{l}\text { Linear } \\
\text { pooling }\end{array}$ \\
\hline $\begin{array}{l}\text { Sperber, } \\
2013[28]\end{array}$ & $\begin{array}{l}\text { Development of a distance } \\
\text { elicitation tool }\end{array}$ & Clinical parameters & Proportions & $\begin{array}{l}\text { Quartile- } \\
\text { bisection method }\end{array}$ & $\begin{array}{l}\text { Computer-based; } \\
\text { non-facilitated }\end{array}$ & $\mathrm{Y}$ & $\begin{array}{l}\text { Y, to } \\
\text { individual, } \\
\text { beta }\end{array}$ & $\begin{array}{l}\text { Linear } \\
\text { pooling }\end{array}$ \\
\hline $\begin{array}{l}\text { Stevenson, } \\
2008 \text { [34] }\end{array}$ & $\begin{array}{l}\text { model-based assessment of the } \\
\text { surgical instrument management } \\
\text { policies to reduce the risk of vCJD } \\
\text { transmission }\end{array}$ & $\begin{array}{l}\text { Epidemiological } \\
\text { parameters } \\
\text { Effectiveness parameters }\end{array}$ & $\begin{array}{l}\text { Count } \\
\text { Proportions } \\
\text { Time to event }\end{array}$ & $\begin{array}{l}\text { probability } \\
\text { distributions }\end{array}$ & $\begin{array}{l}\mathrm{NR} ; \\
\text { facilitated* }\end{array}$ & NR & $\begin{array}{l}Y \\
\text { (Beta or } \\
\text { normal) }\end{array}$ & NR \\
\hline $\begin{array}{l}\text { Stevenson, } \\
2009[30]\end{array}$ & $\begin{array}{l}\text { Cost-effectiveness of an RCT to } \\
\text { establish whether } 5 \text { or } 10 \text { years of } \\
\text { biphosphonate treatment is the } \\
\text { better duration for women ait prior } \\
\text { fracture }\end{array}$ & Effectiveness parameters & Relative risk & Bisection method & & $\mathrm{Y}$ & $\begin{array}{l}\text { Y } \\
\text { (to both } \\
\text { individual and } \\
\text { aggregated; } \\
\text { lognormal) }\end{array}$ & sampling \\
\hline
\end{tabular}

Note: $\mathrm{NR}=$ not reported; ${ }^{*}=$ not explicit, but implied in the text 
Table 4. Critical appraisal of included studies

\begin{tabular}{|c|c|c|c|}
\hline Article & Consideration of validity & Consideration of reliability & Consideration of feasibility \\
\hline $\begin{array}{l}\text { Bojke, } 2010 \\
\text { [27] }\end{array}$ & $\begin{array}{l}\text { Experts given a summary of } \\
\text { their responses and the } \\
\text { opportunity to feedback } \\
\text { and/or restart the } \\
\text { questionnaire Authors note } \\
\text { heterogeneity of responses } \\
\text { and discuss possible causes for } \\
\text { this. }\end{array}$ & $\begin{array}{l}\text { Training: experts given background } \\
\text { information and went through some } \\
\text { example questions } \\
\text { Elicitation task: method described } \\
\text { Calibration: weights were attributed } \\
\text { based on a seed question; aggregation of } \\
\text { responses conducted both with and } \\
\text { without weights }\end{array}$ & $\begin{array}{l}\text { Response rate: } 5 / 16(31 \%) \\
\text { technical burden is considered as a } \\
\text { possible cause for the low response rate. } \\
\text { Expert selection: } \\
\text { Authors recognise trade-off between the } \\
\text { geographical area for recruitment and the } \\
\text { generalizability of the study, and discuss } \\
\text { possibility that experts participating might } \\
\text { be different from those not participating }\end{array}$ \\
\hline $\begin{array}{l}\text { Brodtkorb } \\
2010[24]\end{array}$ & NR & NR & NR \\
\hline $\begin{array}{l}\text { Colbourn, } \\
2007[33]\end{array}$ & NR & NR & $\begin{array}{l}\text { Expert selection: } 4 \text { experts participated } \\
\text { Response rate: NR }\end{array}$ \\
\hline $\begin{array}{l}\text { Garthwaite, } \\
2008[21]\end{array}$ & $\begin{array}{l}\text { Authors report "good practice } \\
\text { in using expert judgement" } \\
\text { during the sessions } \\
\text { Each expert's responses were } \\
\text { validated with those of other } \\
\text { experts, but exact procedure is } \\
\text { not reported }\end{array}$ & $\begin{array}{l}\text { Elicitation task: method described } \\
\text { To prevent the expert from providing } \\
\text { unreliable responses, questions were } \\
\text { simplified to Bernoulli trials (only two } \\
\text { possible outcomes) } \\
\text { Multivariate estimates are recorded } \\
\text { separately } \\
\text { It is unclear whether mathematical } \\
\text { aggregation was conducted }\end{array}$ & $\begin{array}{l}\text { Expert selection: experts were "well } \\
\text { chosen" } \\
\text { Training: experts given an information } \\
\text { pack; a facilitator was present in all the } \\
\text { sessions } \\
\text { Response rate: } 4 / 4 \text { (100\%) Authors noted } \\
\text { that some responses provided by one } \\
\text { expert could not be used fully. }\end{array}$ \\
\hline $\begin{array}{l}\text { Girling, } \\
2007[31]\end{array}$ & $\begin{array}{l}\text { Authors compare results with } \\
\text { unpublished data and } \\
\text { conclude they were "similar". } \\
\text { No other validity } \\
\text { considerations are reported }\end{array}$ & $\begin{array}{l}\text { Elicitation task: it is reported that "the } \\
\text { elicitation procedure was that described } \\
\text { in Garthwaite et al.“ [10], but method } \\
\text { used is unclear, as the referenced paper } \\
\text { describes several elicitation methods }\end{array}$ & $\begin{array}{l}\text { Expert selection: } 5 \text { clinical experts } \\
\text { group elicitation }\end{array}$ \\
\hline $\begin{array}{l}\text { Haakma } \\
2011[25]\end{array}$ & $\begin{array}{l}\text { Experts were given a visual } \\
\text { representation of their } \\
\text { estimates and the opportunity } \\
\text { to adjust their responses }\end{array}$ & $\begin{array}{l}\text { Training: experts were given background } \\
\text { information and explanation of the } \\
\text { elicitation purpose and process. } \\
\text { Elicitation task: method described } \\
\text { Calibration: based on the experts' } \\
\text { background experience (years of } \\
\text { experience, number of cases seen per } \\
\text { week) }\end{array}$ & $\begin{array}{l}\text { Alternative elicitation methods were } \\
\text { assessed in q pilot study with three } \\
\text { experts, and method chosen on basis of } \\
\text { ease of use. } \\
\text { One expert was excluded from the study } \\
\text { as responses were considered as an } \\
\text { outlier } \\
\text { Experts selection: described } \\
\text { Response rate: } 17 / 18 \text { (one expert's } \\
\text { estimates were not used) }\end{array}$ \\
\hline $\begin{array}{l}\text { Leal, } 2007 \\
{[26]}\end{array}$ & $\begin{array}{l}\text { Feedback was requested from } \\
\text { the experts on the } \\
\text { distributions fitted to their } \\
\text { summaries. } \\
\text { Experts could also provide } \\
\text { feedback on the format and } \\
\text { content of the task. }\end{array}$ & $\begin{array}{l}\text { Experts selection: chosen to represent } \\
\text { the population of patients. } \\
\text { Training: experts given background } \\
\text { information and instructions to complete } \\
\text { the questionnaire, but it is unclear if } \\
\text { example questions were used } \\
\text { Elicitation task: method described } \\
\text { Impact of covariates limited by using } \\
\text { Bernoulli trials (only two possible } \\
\text { outcomes for each question) } \\
\text { Calibration: considered but not used, as } \\
\text { limited number of experts and the novelty } \\
\text { of the topic }\end{array}$ & $\begin{array}{l}\text { Alternative elicitation tools assessed in } \\
\text { pilot study and the "four complementary } \\
\text { intervals" method chosen on basis of } \\
\text { reported ease of use. } \\
\text { Response rate: } 6 \text { / } 12(50 \%)\end{array}$ \\
\hline $\begin{array}{l}\text { Meads, } \\
2013[32]\end{array}$ & $\begin{array}{l}\text { Validity tested by comparison } \\
\text { with published data }\end{array}$ & $\begin{array}{l}\text { Training: presentation of the project and } \\
\text { the summaries to be elicited given to } \\
\text { experts. Example questions were used. } \\
\text { Elicitation task: method described }\end{array}$ & $\begin{array}{l}\text { Experts selection: } 21 \text { experts participated } \\
\text { Sessions conducted on the occasions of } \\
\text { several specialist meetings. } \\
\text { Response rate: NR }\end{array}$ \\
\hline McKenna, & NR & Training: not explicitly reported, but a & Response rate: $5 / 7$ ( $71 \%$ ) completed the \\
\hline
\end{tabular}




\begin{tabular}{|c|c|c|c|}
\hline Article & Consideration of validity & Consideration of reliability & Consideration of feasibility \\
\hline 2009 [29] & & $\begin{array}{l}\text { sample of the questionnaire used is } \\
\text { reported with background information } \\
\text { and instructions. } \\
\text { Elicitation task: method described } \\
\text { overconfidence limited by first eliciting } \\
\text { extremes }\end{array}$ & $\begin{array}{l}\text { exercise } \\
\text { The reasons why two experts failed to } \\
\text { complete the questionnaire are not } \\
\text { reported. }\end{array}$ \\
\hline $\begin{array}{l}\text { Soares, } \\
2011[12]\end{array}$ & $\begin{array}{l}\text { Experts given visual } \\
\text { representations of their } \\
\text { estimates and could amend, if } \\
\text { necessary. } \\
\text { Elicited opinions were also } \\
\text { validated with published data } \\
\text { where possible }\end{array}$ & $\begin{array}{l}\text { Expert selection: selection bias minimised } \\
\text { by selecting experts from relevant } \\
\text { settings (hospital and community-based; } \\
\text { both specialists and generalists). } \\
\text { Training: experts given a 2-hour training } \\
\text { session } \\
\text { Elicitation task: method described } \\
\text { Impact of covariates limited by using } \\
\text { binary outcomes } \\
\text { Calibration: evaluated in a pilot exercise, } \\
\text { but not used in main elicitation exercise, } \\
\text { as difficulty in assessing the } \\
\text { appropriateness of seed questions. }\end{array}$ & $\begin{array}{l}\text { Alternative elicitation methods and } \\
\text { calibration assessed in a pilot study. } \\
\text { Response rate: } 23 / 23(100 \%) \\
\text { Authors report some missing values and } \\
\text { one expert providing some inconsistent } \\
\text { responses. }\end{array}$ \\
\hline $\begin{array}{l}\text { Speight, } \\
2006[14]\end{array}$ & NR & Elicitation task: method described & $\begin{array}{l}\text { Experts selection: } 9 \text { clinical experts } \\
\text { participated } \\
\text { Response rate: NR }\end{array}$ \\
\hline $\begin{array}{l}\text { Sperber, } \\
2013[28]\end{array}$ & $\begin{array}{l}\text { Experts given visual } \\
\text { representations (histogram, } \\
\text { fitted distribution) of their } \\
\text { responses. }\end{array}$ & $\begin{array}{l}\text { Training: background information given. } \\
\text { Purpose and process of elicitation } \\
\text { described to experts. } \\
\text { Elicitation task: method described } \\
\text { Calibration: compared results of the } \\
\text { mathematical aggregation with response } \\
\text { of the clinical collaborator in the study } \\
\text { team, and with the distribution of median } \\
\text { responses from the experts. }\end{array}$ & $\begin{array}{l}\text { Some responses were found invalid or } \\
\text { inconsistent, mainly due to lack of specific } \\
\text { guidance for the respondents }\end{array}$ \\
\hline $\begin{array}{l}\text { Stevenson, } \\
2008 \text { [34] }\end{array}$ & $\begin{array}{l}\text { Elicited responses were shown } \\
\text { to other experts for comment }\end{array}$ & $\begin{array}{l}\text { Training: experts given background } \\
\text { information and available literature } \\
\text { Elicitation task: reported use of "formal } \\
\text { elicitation techniques", but no other } \\
\text { details are provided }\end{array}$ & NR \\
\hline $\begin{array}{l}\text { Stevenson, } \\
2009[30]\end{array}$ & $\begin{array}{l}\text { Fitted distribution was } \\
\text { validated by discussing further } \\
\text { percentiles from the experts. } \\
\text { Experts had an opportunity to } \\
\text { adjust their summaries, or } \\
\text { consider an alternative } \\
\text { parametric distribution. } \\
\text { Combined distribution was } \\
\text { also validated by the experts. }\end{array}$ & $\begin{array}{l}\text { Expert selection: the participating experts } \\
\text { were part of the study team. } \\
\text { Elicitation task: method described }\end{array}$ & $\begin{array}{l}\text { Experts selection: Three clinical experts } \\
\text { participated } \\
\text { Response rate: NR }\end{array}$ \\
\hline
\end{tabular}

Note: $\mathrm{NR}=$ not reported 